\title{
Uptake and translocation of organophosphates and other emerging contaminants in food and forage crops
}

\author{
Trine Eggen • Eldbjørg S. Heimstad • \\ Arne O. Stuanes • Hans Ragnar Norli
}

Received: 2 September 2012 / Accepted: 22 November 2012 /Published online: 19 December 2012

(C) Springer-Verlag Berlin Heidelberg 2012

\begin{abstract}
Emerging contaminants in wastewater and sewage sludge spread on agricultural soil can be transferred to the human food web directly by uptake into food crops or indirectly following uptake into forage crops. This study determined uptake and translocation of the organophosphates tris(1-chloro-2-propyl) phosphate (TCPP) (log $K_{\text {ow }}$ $2.59)$, triethyl-chloro-phosphate (TCEP) $\left(\log K_{\text {ow }} 1.44\right)$, tributyl phosphate (TBP) $\left(\log K_{\text {ow }} 4.0\right)$, the insect repellent $N, N$-diethyl toluamide (DEET) $\left(\log K_{\text {ow }} 2.18\right)$ and the plasticiser $N$-butyl benzenesulfonamide (NBBS) $\left(\log K_{\text {ow }} 2.31\right)$ in barley, wheat, oilseed rape, meadow fescue and four cultivars of carrot. All species were grown in pots of agricultural soil, freshly amended contaminants in the range of
\end{abstract}

Responsible editor: Philippe Garrigues

Electronic supplementary material The online version of this article (doi:10.1007/s11356-012-1363-5) contains supplementary material, which is available to authorized users.

T. Eggen $(\bowtie)$

Bioforsk, Norwegian Institute for Agricultural

and Environmental Research, Postveien 213,

4353 Klepp St., Norway

e-mail: Trine.Eggen@bioforsk.no

E. S. Heimstad

Norwegian Institute of Air Research (NILU),

Hjalmar Johansens gate 14,

9296 Tromso, Norway

A. O. Stuanes

Norwegian University of Life Sciences, Box 5003,

$1432 \AA$ As, Norway

H. R. Norli

Bioforsk, Norwegian Institute for Agricultural and Environmental Research, Høgskoleringen 7, 1432 Ås, Norway
$0.6-1.0 \mathrm{mg} / \mathrm{kg}$ dry weight, in the greenhouse. The bioconcentration factors for root (RCF), leaf (LCF) and seed (SCF) were calculated as plant concentration in root, leaf or seed over measured initial soil concentration, both in dry weight. The chlorinated flame retardants (TCEP and TCPP) displayed the highest bioconcentration factors for leaf and seed but did not show the same pattern for all crop species tested. For TCEP, which has been phased out due to toxicity but is still found in sewage sludge and wastewater, LCF was 3.9 in meadow fescue and 42.3 in carrot. For TCPP, which has replaced TCEP in many products and also occurs in higher residual levels in sewage sludge and wastewater, LCF was high for meadow fescue and carrot (25.9 and 17.5, respectively). For the four cultivars of carrot tested, the RCF range for TCPP and TCEP was 10-20 and 1.7-4.6, respectively. TCPP was detected in all three types of seeds tested (SCF, 0.015-0.110). Despite that DEET and NBBS have $\log K_{\text {ow }}$ in same range as TCPP and TCEP, generally lower bioconcentration factors were measured. Based on the high translocation of TCPP and TCEP to leaves, especially TCPP, into meadow fescue (a forage crop for livestock animals), ongoing risk assessments should be conducted to investigate the potential effects of these compounds in the food web.

Keywords Cereals $\cdot$ Oilseeds $\cdot$ Carrot $\cdot$ Grass . Organophosphates · TCPP · TCEP · TBP · NBBS · DEET · Emerging contaminants $\cdot$ Meadow fescue $\cdot$ Wastewater

\section{Introduction}

Food safety is an important global issue receiving high priority worldwide. Transfer of contaminants from soil, water and air to the food chain is one aspect of food safety, and identification of sources, transfer pathways and 
environmental residue levels of emerging contaminants are attracting great attention. For instance, pharmaceuticals, musk compounds and organophosphates up to micrograms per liter or milligrams per kilogram dry weight (dw) have been be found in water or sewage sludge (CalderónPreciado et al. 2011; Lee et al. 2010; Muñoz et al. 2009; Reemtsma et al. 2006). Residue levels in waste water and sewage sludge for selected emerging contaminants studied in the present work is summarized in Table 1 (Glassmeyer et al. 2005; Green et al. 2008; Huppert et al. 1998; Leonards et al. 2011; Marklund et al. 2005; Nakada et al. 2006; Terzic et al. 2008).

Contaminants can be transported to soil via several routes. Manure and sewage sludge are used as fertilisers and soil conditioner on agricultural soils while effluent from wastewater treatment plants (WWTPs) is used for irrigation. In addition, manure and sewage are used to manufacture commercial mature compost and soil-based growing mediums, which are commonly used in domestic gardens. Sewage sludge and wastewater are known to contain a large mixture of different legacy and emerging contaminants including high-volume human pharmaceuticals and personal care additives, e.g. review by Harrison et al. (2006) and detected in different screening projects (Calderón-Preciado et al. 2011; Díaz-Cruz et al. 2009; Duarte-Davidson and Jones 1996; Kolpin et al. 2002; Muñoz et al. 2009), while manure can contain residues of veterinary pharmaceuticals from medication of livestock animals (Campagnolol et al. 2002; Furtula et al. 2010; Kolpin et al. 2002; Zhao et al. 2010). Examples of such compounds which also are found to be taken up by plants are galaxolide, tonalide, triclosane, enrofloxacin, carbamazepine, metformin and trimethoprim (Boxall et al. 2006; Eggen and Lillo 2012; Macherius et al. 2012; Migliore et al. 2003).

Emerging contaminants are new substances found or expected to be found in the environment and which may have potential toxic effects but yet not regulated due to lack of persistent, toxicity and bioaccumulation data. Many of these compounds are additives used widely in everyday industrial and household products, such as flame retardants for textiles and other products, surface-active substances used as detergents or water and oil repellent products, fragrances used in hygienic, cosmetic and cleaning products and plasticisers used in products such as toys and food containers (Eriksson et al. 2003; Goldman 1998; Marklund et al. 2003; Slack et al. 2005). Emerging contaminants cover a wide range of properties, and unlike many legacy organic hydrophobic contaminants (e.g. persistent organic pollutants), many of these new compounds tend to be more polar and water-soluble but are still persistent in the environment.

Chemical substances recognised as an environmental or human threat are phased out and replaced with less hazardous substances. For instance, triethyl-chloro-phosphate
(TECP) has been phased out in Europe (Andresen et al. 2004) due to its toxicity (European Commission 2009; WHO World Health Organization 1998). However, tris(1chloro-2-propyl) phosphate (TCPP), which has replaced TCEP in many products (Quednow and Püttmann 2009), is also considered to be potentially carcinogenic and is undergoing a health and environmental risk assessment (European Commission 2008). In addition, the detergent tributyl phosphate (TBP), the insect repellent $N, N$-diethyl toluamide (DEET), which is widely used in consumer products such as anti-mosquito agents or certain types of sportswear, and the plasticiser $N$-butyl benzenesulfonamide (NBBS) are all emerging contaminants that are being evaluated for their potential environmental and human health risks (Aronson et al. 2011; OECD April 2001; Strong et al. 1991).

Transport of water and solutes, including contaminants, from soil via plant roots to aboveground compartments is driven by the water potential gradient created by plant transpiration (McFarlane 1995). It has been shown that many of the legacy and less hydrophilic organic pollutants, e.g. polychlorinated biphenyls, dichlorodiphenyltrichloroethane and its metabolites, polyaromatic hydrocarbons and dioxins, can be taken up from the soil via roots (Inui et al. 2008b; White 2010; Whitfield-Åslund et al. 2008; Zohair et al. 2006). However, except for some plant speciesdependent difference for instance for Vivica cracca (Ficko et al. 2010) and certain varieties of Cucurbita pepo ssp (pumpkin and zucchini) (White 2010; Whitfield-Åslund et al. 2008), uptake of these compounds via roots is general low. Due to their higher polarity, the emerging compounds might have a greater capability to be taken up by plant roots and further translocated within plants. However, knowledge of if and how they transfer into the terrestrial food web is still scarce. Many polar emerging contaminants have a high potential to pass through treatment processes commonly used for landfill leachates or in WWTPs and can thus be detected in effluents and the environment (Nakada et al. 2010). Thus, more knowledge of environment-food web transfer of such compounds is important.

In recent decades, a number of plant uptake models ranging in scope from simple steady-state equations with one input parameter to compartment models containing several dynamic uptake, intra-plant processes and input parameters have been established to predict uptake of compounds (Briggs et al. 1982; Chiou et al. 2001; Dettenmaier et al. 2009; Rein et al. 2011; Ryan et al. 1988; Trapp 2000). However, in order to verify or adjust existing uptake models for emerging contaminants, experimental or controlled field data are needed.

The main objective of the present work was to compare uptake and translocation of selected polar and semipolar emerging organic contaminants with different 


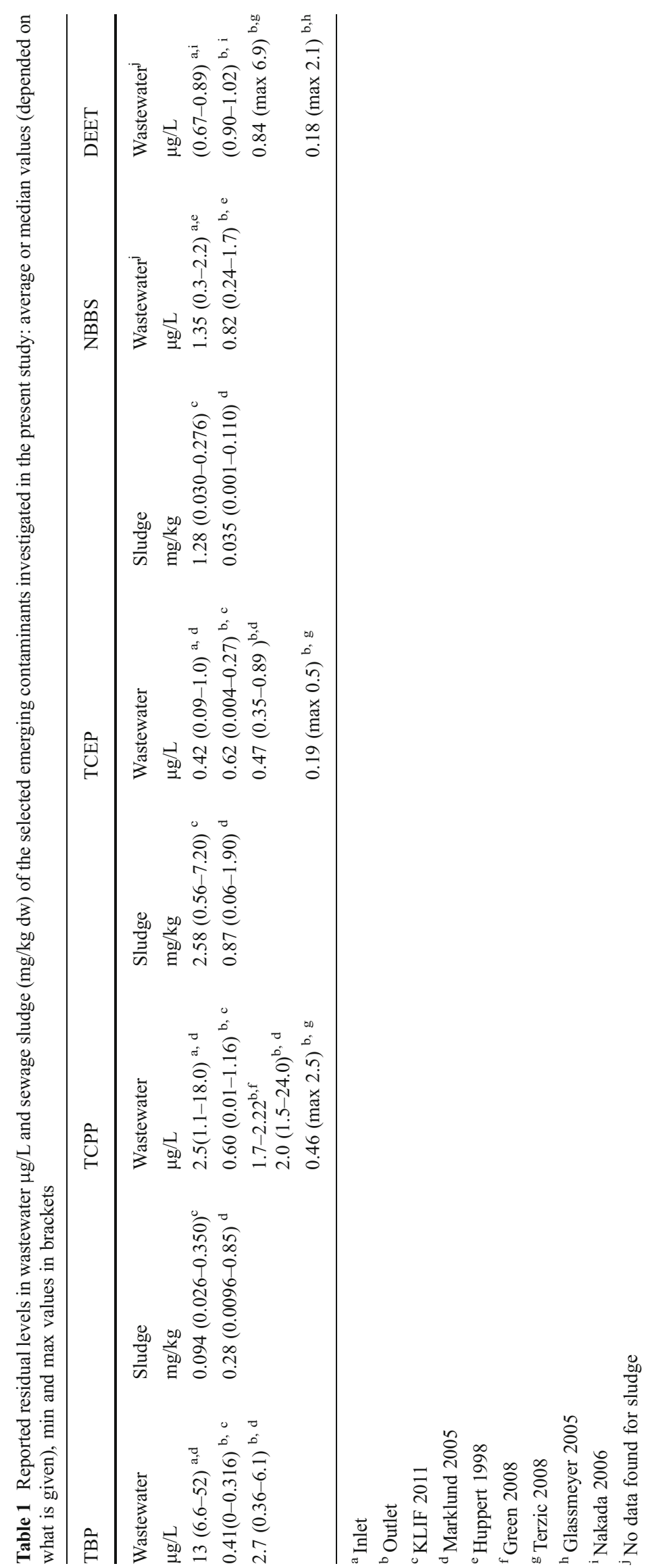


structures and properties in an experimental growth study using different high-volume and agriculturally important crop plants. This is important knowledge related to human health risk assessments where transfer of contaminants from soil to edible plant compartments is included. Verification of the experimental data in dynamic plant uptake models was performed in a separate study (Trapp and Eggen, in press Environmental Science and Pollution Research). The crop plants included in the study were cereals (barley, Hordeum vulgare; wheat, Triticum aestivum), a grass forage (meadow fescue, Festuca pratense), oily rape seed (Brassica rapa) and root vegetable (carrot, Daucus carota). The emerging organic contaminants analysed were: the flame retardants TCPP and TECP, the detergent TBP, the plasticiser NBBS, and the insect repellent DEET. A summary of the main structure and chemical and physical properties of these five substances at relevant $\mathrm{pH}$ is presented in Table 2. In order to compare uptake and translocation of contaminants in different plant species and organs, it is necessary to apply soil concentration which is analytical measurable. Thus, clean soil with artificial added contaminants was used as experimental approach.

\section{Materials and methods}

Plant uptake experiment

The study was a greenhouse pot experiment conducted at Bioforsk Vest Særheim between December 2008 and April 2009. A detailed description of the experimental procedure is given elsewhere (Eggen et al. 2011), and it is only briefly summarised below.

\section{Soil characterisation}

Loamy sand soil from an agricultural field in West Norway was sieved $(<4 \mathrm{~mm})$ and mixed with a controlled-release fertiliser (3 g/kg soil, Multicote 4, (N/K/P) 15:7:15 (2+) TE, Haifa Chemicals Ltd.) using a cement mixer for approximately $10 \mathrm{~min}$. The soil had $0.7 \mathrm{~g} \mathrm{~kg}^{-1}$ total organic carbon,

Table 2 Selected physico-chemical properties of the test compounds used in the present study

\begin{tabular}{|c|c|c|c|c|c|c|c|c|c|c|}
\hline $\begin{array}{l}\text { Test compound } \\
\text { and application }\end{array}$ & Structure (at pH 5.5) & CAS-no. & MW & $\log K_{\text {ow }}$ & $\begin{array}{l}\text { Half-life } \\
\text { in soil } \\
\text { (d) }\end{array}$ & $\begin{array}{c}\text { Henry's Law } \\
\text { constant } \\
(\text { atm-m } \\
\left.\text { mole }^{-1}\right) \\
\end{array}$ & $\begin{array}{c}\text { Water } \\
\text { solubility } \\
\text { (mg/L) }\end{array}$ & $\begin{array}{l}\text { Polaris- } \\
\text { ability }^{\mathrm{d}} \\
\left(\AA^{3}\right)\end{array}$ & $\begin{array}{c}\text { Electron } \\
\text { Affinity }^{\mathrm{d}} \\
(\mathrm{eV})\end{array}$ & $\begin{array}{l}\text { Electro- } \\
\text { negativity } \\
(\mathrm{eV})\end{array}$ \\
\hline $\begin{array}{l}\text { Tris(2-Chloroethyl) } \\
\text { Phosphate (TCEP). } \\
\text { Flame retardant }\end{array}$ & & $115-96-8$ & 285.5 & $1.44 \exp ^{a}$ & 120 est $^{b}$ & $\begin{array}{l}3.29 \mathrm{E}-06 \text { est } \\
25^{\circ} \mathrm{C}^{\mathrm{a}}\end{array}$ & $\begin{array}{c}7000 \text { exp } \\
25^{\circ} \mathrm{C}^{\mathrm{a}}\end{array}$ & 21.72 & 1.992 & 6.494 \\
\hline $\begin{array}{l}\text { Tris(1-chloro-2- } \\
\text { propyl) phosphate } \\
\text { (TCPP). } \\
\text { Flame retardant }\end{array}$ & & $13674-84-5$ & 327.6 & $2.59 \exp ^{a}$ & 120 est $^{\mathrm{b}}$ & $\begin{array}{l}5.96 \mathrm{E}-08 \\
\text { est } 25^{\circ} \mathrm{C}^{\mathrm{a}}\end{array}$ & $\begin{array}{c}1200 \exp \\
25^{\circ} \mathrm{C}^{\mathrm{a}}\end{array}$ & 27.293 & 1.916 & 6.394 \\
\hline $\begin{array}{l}\text { Tributyl phosphate } \\
\text { (TBP). } \\
\text { Detergent }\end{array}$ & & $126-73-8$ & 266.3 & $4.00 \exp ^{a}$ & 17 est $^{b}$ & $\begin{array}{l}1.41 \mathrm{E}-06 \text { est } \\
25^{\circ} \mathrm{C}^{\mathrm{a}}\end{array}$ & $\begin{array}{l}280 \exp \\
25^{\circ} \mathrm{C}^{a}\end{array}$ & 26.836 & 1.242 & 5.805 \\
\hline $\begin{array}{l}\text { N.N-diethyl } \\
\text { toluam ide (DEET). } \\
\text { Insect repellent }\end{array}$ & & $134-62-3$ & 191 & $2.18 \exp ^{a, c}$ & 75 est $^{\mathrm{b}}$ & $\begin{array}{l}2.08 \mathrm{E}-08 \text { est } \\
25^{\circ} \mathrm{C}^{\mathrm{a}}\end{array}$ & $\begin{array}{l}912 \text { est } \\
25^{\circ} \mathrm{C}^{a}\end{array}$ & 23.843 & 0.157 & 4.63 \\
\hline $\begin{array}{l}\text { N-butyl } \\
\text { benzenesulfon- } \\
\text { amide (NBBS). } \\
\text { Plasticiser }\end{array}$ & & 3622-84-2 & 213.3 & 2.31 est $^{b, c}$ & 30 est $^{b}$ & $\begin{array}{l}2.17 \mathrm{E}-06 \text { est } \\
25^{\circ} \mathrm{C}^{\mathrm{b}}\end{array}$ & $\begin{array}{l}398 \text { est } \\
25^{\circ} \mathrm{C}^{\mathrm{b}}\end{array}$ & 21.199 & 0.763 & 5.451 \\
\hline${ }^{\mathrm{a}} \operatorname{Exp}=$ experimen & & ta from $\mathrm{C}$ & nemIDI & us Advan & ed http:// & hem.sis.nlm.r & ih.gov/che & nidplus/c & midheavy & \\
\hline
\end{tabular}


$\mathrm{pH} 6.0(v / v=1: 2.2)$ and cation exchange capacity of $46.6 \mathrm{mmol}_{\mathrm{c}} \mathrm{kg}^{-1}$.

\section{Test compounds}

The selected test substances were TCPP, TECP, TBP, DEET and NBBS. All organophosphates were supplied by Chiron AS, Trondheim, Norway, and DEET and NBBS by SigmaAldrich, Norway, with purity better than $98 \%$ for all compounds.

\section{Spiking procedure}

Stock solutions of the test compounds $(40 \mathrm{mg} / \mathrm{mL})$ were dissolved in acetone (approximately 5-10 mL). One millilitre stock solution was then diluted in $50 \mathrm{~mL}$ distilled water (all test compounds added together), after which it mixed thoroughly by hand with $4.0 \mathrm{~kg}$ dw soil and added to each 4L pot. Each pot was prepared separately. The nominal estimated concentration of test compound in each pot was $1 \mathrm{mg}$ / $\mathrm{kg}$. Soil samples were taken directly after spiking and stored at $4{ }^{\circ} \mathrm{C}$, approximately 3 weeks, until analysis to determine the actual initial soil concentration.

\section{Selected plants and growth conditions}

The selected plant species are all important crop or forage plants: barley (H. vulgare cv. Edel) (root, leaf, grain); wheat (T. aestivum cv. Bjarne) (grain); and meadow fescue ( $F$. pratense cv. Fure) (root, leaf); oilseed rape (B. rapa cv. Valo) (seed); and four carrot cultivars (D. carota ssp. sativus cvs): Napoli (root and leaf), Amagar (root), Nutri-Red (root) and Rothild (root). Barley, meadow fescue and carrot cv. Napoli were chosen as model-plants, and all plant compartments were analysed. Only the edible compartments were analysed in the other plant species.

The solvent (acetone) residues in soil were allowed to evaporate for 3 days before seeds were sown. The number of plants per pot, selected based optimal biomass of plants in $4 \mathrm{~L}$ pots, was 5, 7, 10, 10 and 20, for carrot, barley, rape, wheat and fescue, respectively. After germination, growth conditions were set to $20 / 14{ }^{\circ} \mathrm{C}$ (day/night) and 16 hday length. The pots (individual trays) were irrigated when necessary to keep them moist, as least once a day, with water fertilised to electrical conductivity $1.5 \mathrm{mS} / \mathrm{cm}$ and $\mathrm{pH}$ 7.4. Control pots without test compounds were grown for all plant species. All treatments were conducted in triplicate.

\section{Harvesting}

Both control and exposed plant materials were harvested when mature or ripe (after 2-3 months). Leaf was cut while root still was in the pots. Roots were carefully washed in tap water. All plant materials were dried ( 1 day at $50^{\circ} \mathrm{C}, 2$ days at $40^{\circ} \mathrm{C}$ ) (controls and exposed material in separate ovens to prevent cross-contamination) immediately after harvesting and stored in paper bags at room temperature until analysis, approximately 3 weeks. Biomass of the plant compartments root and leaf in each pot was weighed before and after drying. A small test to compare concentration levels in dried and not-dried seeds $(n=3)$ was performed to check for significant evaporation during the drying processes (data not shown).

Analytical methods

Sample preparation followed the QuEChERS (quick, easy, cheap, effective, rugged and safe) method (Lehotay et al. 2005). In brief, plant and soil samples were spiked with 2-brom-biphenyl as an internal standard and extracted with double-distilled water and acetonitrile. All samples were initially cleaned up with primary-secondary amine. Further clean-up of seeds (DSC-18 sorbent) and of carrot, meadow fescue and barley (Envi-Carb) was performed. The extracts were analysed using an Agilent $6890 \mathrm{~N}$ gas chromatograph (GC) connected to an Agilent 5973 mass spectrometer with an inert ion source operated in selected ion monitoring mode. The GC was equipped with a Gerstel Programmable Temperature Vaporising Injector (Mühlheim Ruhr, Germany). Separation was performed using a fused silica J\&W Scientific HP-5MSI $(0.25 \mathrm{~mm}$ i.d. $\times$ $30 \mathrm{~m})$ with $0.25 \mu \mathrm{m}$ film thickness. For details of sample preparation, analysis and information about retention time, quantification ions and recovery, please see Table S1 and S2 in the Electronic Supplementary Material. Except for DEET in meadow fescue leaf and TBP in carrot root and meadow fescue leaf, the limit of quantification (LOQ) was set to $0.01 \mu \mathrm{g} / \mathrm{g}$. In meadow fescue leaf, the LOQ had to be increased to $0.05 \mu \mathrm{g} / \mathrm{g}$. Unfortunately, no LOQ was set at $0.01 \mathrm{ug} / \mathrm{g}$ for DEET in meadow fescue leaf and TBP in carrot root due to interferences. However, in real samples, the concentrations were relative high (DEET $\geq 0.08 \mu \mathrm{g} / \mathrm{g}$ and $\mathrm{TBP} \geq$ $0.92 \mu \mathrm{g} / \mathrm{g}$ ) and the interferences became insignificant. All results for plant and soil concentrations were calculated based on dry weight.

Statistical analysis

Differences in concentrations of the compounds between species were tested using the software PROC GLM in SAS 9.0 (SAS Institute, Cary, NC, USA) with Ryan or Ryan-Einot-Gabriel-Welsch Q multiple-comparison test. For all the tests, the significance level was set at $p<0.05$. 


\section{Results and discussion}

The nominal initial soil concentration was $1 \mathrm{mg} / \mathrm{kg}$, but the actual measured initial soil concentration $(n=4$, average \pm standard deviation) for TBP, TCEP, TCPP, DEET and NBBS was $0.62 \pm 0.05,0.85 \pm 0.11,0.72 \pm 0.12,1.00 \pm 0.12$ and 1.03 $\pm 0.12 \mathrm{mg} / \mathrm{kg}$, respectively. The present study sought to compare root uptake and translocation of different potential contaminants to leaves and seeds, so it was important to select an initial soil concentration that was realistic for detection of the contaminants in plant material, although potentially higher than a realistic exposure situation. The initial soil values selected are comparable to those used in other studies, and spiking of soil is also a commonly used technique (Boxall et al. 2006; Gao et al. 2005; Winker et al. 2010; Wu et al. 2010). Data on residual levels of emerging contaminants in sewage sludge, particularly regarding DEET and NBBS, are scarce, and the concentrations in sewage sludge can vary widely (Harrison et al. 2006; Clarke and Smith 2011). Therefore, realistic concentrations in agricultural soil are actually not known. However, while many previous studies have been short-term, e.g. hydroponic cultures with incubation commonly up to a few weeks (Briggs et al. 1982; Murano et al. 2010), the present study involved plant growth over 17 weeks, providing a more realistic picture that accounted for concentration dilution during growth, soil degradation and possible in planta metabolism (Schröder et al. 2007).

\section{Plant uptake and translocation}

The bioconcentration factors for root (RCF), leaf (LCF) and seed (SCF) were calculated as concentration in plant compartments (milligrams per kilogram dry weight) over actual measured initial soil concentration (milligrams per kilogram dry weight). Despite high variations between species and cultivars, the concentrations in roots were generally lower than those in leaves for all test compounds except TBP (log $K_{\text {ow }}=4$ ) in carrots (Fig. 1a-c). For roots (Fig. 1a), a general higher uptake in carrots than in barley and meadow fescue was observed, with TCPP showing particularly high uptake in carrot $(\mathrm{RCF}=10-20)$. RCF for TBP and DEET in carrot was in the range 1.7-4.6 and 0.4-2.3, respectively, while it was even lower (range, 0.2-0.7) in NBBS and TCEP.

Comparison of RCF between the four cultivars of carrot revealed a significant $(p<0.05)$ difference for TBP, with higher levels in cv. Napoli and cv. Nutri Red (RCF, 4.44.6) than those of cv. Amagar and cv. Rothild (1.6-2.5) and for DEET where cv. Nutri Red was higher than Amagar (Fig. 1a). However, there was a general trend for the highest average RCF for all compounds tested to be found in $\mathrm{cV}$. Napoli and the lowest in cv. Amagar (Fig. 1a). In contrast, an opposite trend is reported for metformin (a cationic pharmaceutical) which showed lower RCF in carrot cv. Napoli than in cv. Amagar, RCF 2 and 10, respectively (Eggen et al. 2011). The highest measured RCF in barley and meadow fescue was 1.4 for TBP in barley and 0.9 for TCPP in meadow fescue, respectively (Fig. 1a). The concentration was below the LOQ for NBBS in both plant species and for TCEP in meadow fescue.

The concentrations in leaves were generally higher than those in roots and also showed a different pattern for different compounds (Fig. 1b). TCEP demonstrated high translocation to leaves, with LCF ranging from 3.9 in meadow fescue to 26 and 42 in barley and carrot, respectively, while the $\mathrm{RCF}$ was $<1$ for all three plant species. Ratio leaf/root TCPP, also with $\mathrm{RCF}<1$ for barley and meadow fescue, showed significantly higher uptake to leaves of meadow fescue than barley (LCF 25.6 and 6.4, respectively) (Fig. 1b). In leaves of carrot cv. Napoli, the concentration of TCPP was comparable to that in roots (RCF and LCF in range 10-20). The LCF for DEET ranged from 2.3 to 7.4 (RCF 0.1-2.6), and barley leaves showed significant higher uptake than meadow fescue and carrot (Fig. 1b). Uptake of TBP to leaves was low, $\mathrm{LCF}<1.2$, for all three plant species with no significant differences. NBBS which was not measurable in roots of barley or meadow fescue was detected in leaves of both barley and carrot cv. Napoli (LCF 0.08-0.5). The high difference between leaf (average $3.3 \mathrm{mg} / \mathrm{kg}$ ) and root $(<0.05 \mathrm{mg} / \mathrm{kg})$ for TCEP in meadow fescue (ratio $>$ 1,000 if concentration in root is estimated to half of $\mathrm{LOQ}=0.025 \mathrm{mg} / \mathrm{kg}$ ) is the highest root-leaf translocation in this study. High root-leaf ratio was also observed for TCEP in barley and carrot (range of 45-75), TCPP in meadow, barley and carrot and DEET in meadow fescue (range, 20-30).

The translocation of test compounds to seeds was low, with only TCPP being detected in wheat, barley and rape and TCEP in barley and rape (Fig. 1c). The concentration of TCPP was significantly higher in barley and rape seeds than in wheat, with SCF $0.110,0.085$ and 0.015 , respectively. The TCEP concentration in rape seeds was significantly higher than that in barley, with SCF 0.097 and 0.034, respectively (Fig. 1c).

The control pots were standing close to the exposed pots, but none of the test compounds were detected above the LOQ in the control plants except for TCPP in control rape seeds, in which had concentrations of $0.010-0.014 \mathrm{mg} / \mathrm{kg}$ (compared with $0.060-0.120 \mathrm{mg} / \mathrm{kg}$ in exposed pots). TCPP and TCEP can both occur in indoor and outdoor air samples (Marklund et al. 2003; Reemtsma et al. 2008), but analysis of leaves and seeds from control plants showed that the greenhouse air atmosphere was not a significant source in the present study. In addition, the Henry's law constant values are low for the test compounds (Table 2), and evaporation from soil to leaves is not expected. Thus, the results 
Fig. 1 Bioconcentration factors in roots (RCF) (a), leaves (LCF) (b) and seeds (SCF) (c) presented as milligram test compound per kilogram dry weight plant material $(n=3)$ per milligram test compound per kilogram dry weight soil $(n=4)$. Average and standard deviation ( $n=3$ pots) is present. The $\log K_{\text {ow }}$ for TBP $=4.0$, TCEP $=$ 1.44; $\mathrm{TCEP}=2.59$; $\mathrm{NBBS}=$ 2.31 and DEET $=2.18$

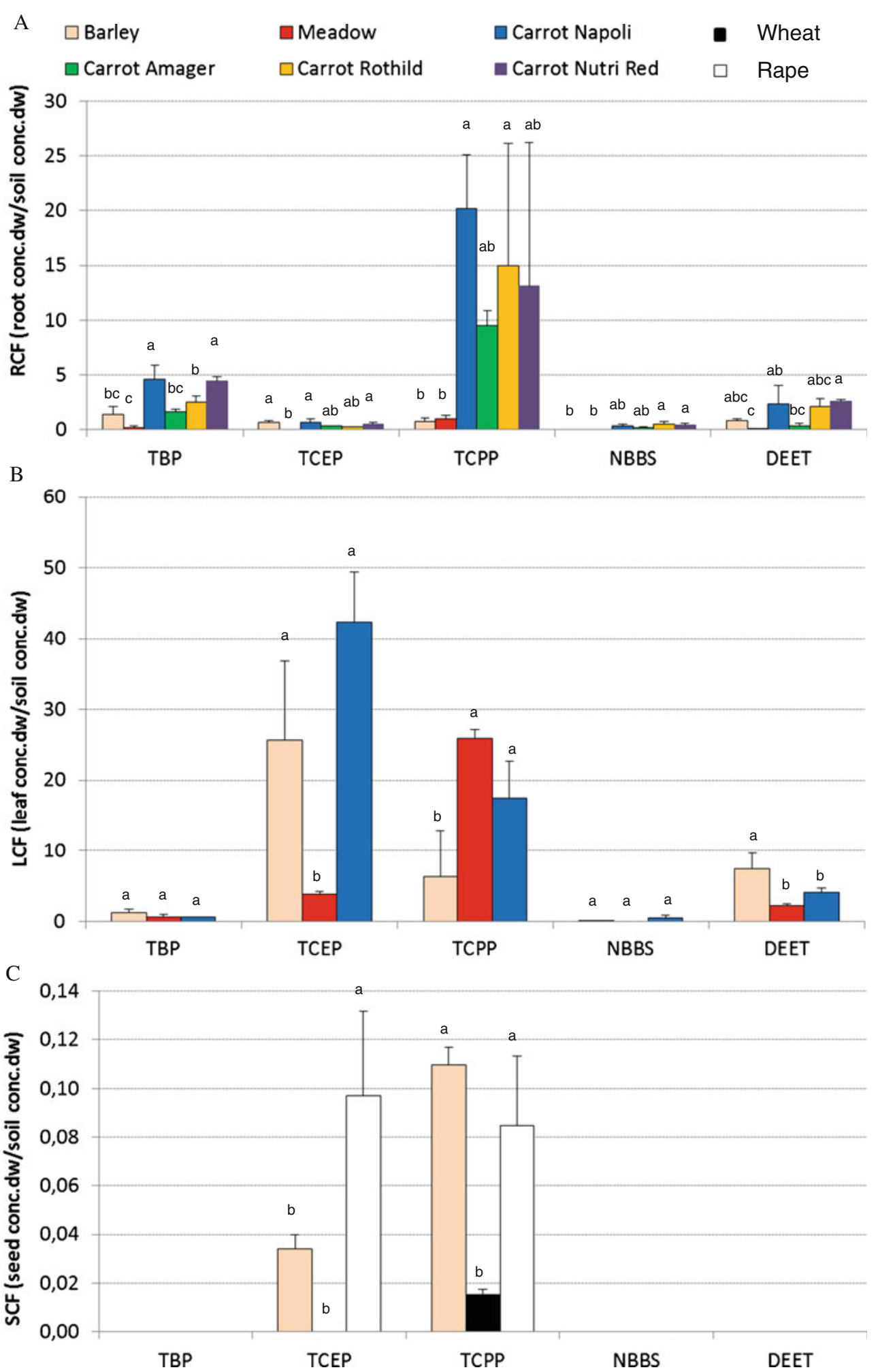

for control leaves and seeds support the assumption that root uptake and translocation was the main transport pathway to aboveground plant compartments.

A high plant species variation was observed in our study, e.g. general higher uptake in carrot roots than meadow fescue and barley, lower uptake of TCEP and DEET in leaves of meadow fescue than barley, and the opposite pattern, higher in meadow fescue than barley leaves was measured for TCPP. A high variation in uptake between species, or even between cultivars, is not unlikely and has previously been reported in several studies (Gonzalez et al. 2005; Inui et al. 2008a; Lunney et al. 2004; White 2002; 
Zhang et al. 2009). Suggested explanations for such variations are differences in quantity and quality of root exudates, plant composition, root structure, biomass, endophytes populations and multi-species interaction (Kelsey and White 2005; Mattina et al. 2006; White et al. 2003a, b) (Khan and Doty 2011; Li et al. 2012). While the focus in food safety is to avoid high uptake and translocation to edible plant compartments, the opposite is the case for phytoremediation. The high translocation of chlorinated organophosphates to leaves of carrot, meadow and barley indicate that species from these plant families might be particularly suitable for phytoremediation for such compounds (Fig. 1, Table 3). High translocation to leaves is also reported for sulfolane (estimated by EPISuit, $\log K_{\text {ow }}-0.24$, water solubility $292.8 \mathrm{~g} / \mathrm{L}$ ) to cattail, Typha latifolia, with leaf/root ratio> 150 (Doucette et al. 2005) and for carbamazepine (estimated by EPISuite, $\log K_{\text {ow }} 2.25$, water solubility $17.7 \mathrm{mg} / \mathrm{L}$ ) to ryegrass, Lolium perenne (Winker et al. 2010). Since there is a clear plant species variance for uptake and translocation for different contaminants, it is necessary to investigate which plant species is most optimal in each case.

The experimental bioconcentration factors found in this study indicate that there is not a clear relationship between $\log K_{\text {ow }}$ and plant uptake and translocation. Generally, LCF was higher (20-42) for TCEP ( $\left.\log K_{\text {ow }} 1.44\right)$ and TCPP (log $\left.K_{\text {ow }} 2.59\right)$ than for DEET and NBBS $\left(\log K_{\text {ow }} 2.18\right.$ and 2.31, respectively) (Fig. 1b). Biodegradation influences the environmental fate of contaminant compounds and TCEP and TCPP, both chlorinated compounds, showed the highest estimated half-lives (Table 2). Thus, since soil biodegradation rates also influence a compounds' potential for transfer to plants, plant uptake models should include degradation kinetic parameters. In theoretical structure-activity studies, the polarisability $\left(\AA^{3}\right)$ of contaminants has been shown to have a good correlation with various physico-chemical properties, including bioconcentration factors (Hong et al. 2009; Papa et al. 2007; Staikovaa et al. 2004) and chemicobiological interactions (Hansch et al. 2003; Karelson and Lobanov 1996; Verma et al. 2005). The passage of xenobiotics through endodermic pores in plant roots is reported to be dependent on chemical polarity and molecular configuration (van Leeuwen and Vermeire 2007). TCEP and TCPP also have higher water solubility, electronegativity and electronaffinity (Heimstad et al. 2001) than the other compounds studied here (Table 2). However, the speciesdependent differences seen in the present study and in several other studies (Collins and Willey 2009; Eggen and Lillo 2012; Zhang et al. 2009) indicate complex biological effects that are not yet understood. For instance, several studies show that both hydrophobic organic compounds and hydrophilic dissociable organic compounds can be present in higher concentrations in roots than in leaves (Herklotz et al. 2010; Migliore et al. 1996), and a hydrophilic cationic pharmaceutical can be accumulated in oily rape seeds (Eggen and Lillo 2012). It is important to reveal regulation of contaminants or emerging contaminants with potential to high uptake and translocation to edible plant compartments like carrot, seeds or forage grasses. Today, it is no regulation or guidelines for emerging contaminants content in food items.

\section{Growth effects}

Plant growth and mortality were visually and quantitatively measured in terms of decline of plant biomass per pot (Fig. 2). Comparison of biomass of root and leaf (given as grams dry weight per pot) grown in control pots and in pot exposed to a mixture of the investigated emerging contaminants is shown in Fig. 2a. Under optimal plant growth conditions, the root-shoot ratio is quite specific for each plant species, but a number of external factors, e.g. nutrient and water supply, can alter this ratio (Marschner 1995). In the present experiment, no difference in the root/leaf ratio was observed for exposed meadow fescue and barley compared with the control (Fig. 2b). However, for the carrot cvs. Napoli and Amagar, the root-leaf ratio was higher in exposed plants (5.6 and 3.0, respectively) than in control plants (1.6). No clear differences were seen for the other two carrot cvs. Rothild and Nutri-Red. The same pattern of higher root-leaf ratio in cvs. Napoli and Amagar exposed to metformin, ciprofloxacin and narasin has been reported in a recently published plant uptake study (Eggen et al. 2011). In addition, root vegetables, e.g. carrot and radish, have been found to be more

Table 3 Summary of measured bioconcentration factor trends in root (RCF), leaf (LCF) and seed (SCF) for the different test compounds independent of statistical significance is shown

\begin{tabular}{|c|c|c|c|c|c|}
\hline $\mathrm{RCF}_{\text {Barley }}$ & $\mathrm{TBP}^{\mathrm{a}}>\mathrm{DEET}^{\mathrm{a}}>\mathrm{TCPP}^{\mathrm{a}}>\mathrm{TCEP}^{\mathrm{a}}$ & $\mathrm{LCF}_{\text {Barley }}$ & $\mathrm{TCEP}^{\mathrm{a}}>\mathrm{DEET}^{\mathrm{b}}>\mathrm{TCPP}^{\mathrm{b}} \sim \mathrm{TBP}^{\mathrm{b}}>\mathrm{NBBS}^{\mathrm{b}}$ & $\mathrm{SCF}_{\text {Barley }}$ & $\mathrm{TCPP}^{\mathrm{a}}>\mathrm{TCEP}^{\mathrm{b}}$ \\
\hline $\mathrm{RCF}_{\text {Meadow }}$ & $\mathrm{TCPP}^{\mathrm{a}}>\mathrm{TBP}^{\mathrm{b}}>\mathrm{DEET}^{\mathrm{b}}$ & $\mathrm{LCF}_{\text {Meadow }}$ & $\mathrm{TCPP}^{\mathrm{a}}>\mathrm{TCEP}^{\mathrm{b}}>\mathrm{DEET}^{\mathrm{c}}>\sim \mathrm{TBP}^{\mathrm{d}}, \mathrm{NBBS}^{\mathrm{d}}$ & $\mathrm{SCF}_{\text {Wheat }}$ & TCPP \\
\hline $\begin{array}{l}\mathrm{RCF}_{\text {Carrot-Napoli }} \\
\text { and Amagar }\end{array}$ & $\mathrm{TCPP}^{\mathrm{a}}>\mathrm{TBP}^{\mathrm{b}}>\mathrm{DEET}^{\mathrm{b}}>\mathrm{TCEP}^{\mathrm{b}} \approx \mathrm{NBBS}^{\mathrm{b}}$ & $\mathrm{LCF}_{\text {Carrot }}$ & $\mathrm{TCEP}^{\mathrm{a}}>\mathrm{TCPP}^{\mathrm{b}}>\mathrm{DEET}^{\mathrm{c}}$ & $\mathrm{SCF}_{\text {Rape }}$ & $\mathrm{TCEP}^{\mathrm{a}}>\mathrm{TCPP}^{\mathrm{a}}$ \\
\hline $\mathrm{RCF}_{\text {Carrot-Rothild }}$ & $\mathrm{TCPP}^{\mathrm{a}}>\mathrm{TBP}^{\mathrm{b}}>\mathrm{DEET}^{\mathrm{b}}>\mathrm{TCEP} \approx \mathrm{NBBS}^{\mathrm{b}}$ & & & & \\
\hline $\mathrm{RCF}_{\text {Carrot-Nutri Red }}$ & $\mathrm{TCPP}^{\mathrm{a}}>\mathrm{TBP}^{\mathrm{b}}>\mathrm{DEET}^{\mathrm{c}}>\mathrm{TCEP}^{\mathrm{d}} \approx \mathrm{NBBS}^{\mathrm{d}}$ & & & & \\
\hline
\end{tabular}

Results of multiple comparison is shown by superscripted letters

Significant differences $(p<0.05)$ are marked 
Fig. 2 Biomass of control and exposed plants given in dry weight (a) and root-leaf ratio based on dry weight (b). Biomass data from plants exposed to emerging contaminants in a previous experiment (Eggen et al. 2011) are marked with an asterisk. Average and standard deviation shown for three or more pots. 'Mixture' is results from the present study where test compounds were added in a mixture cocktail of TBP, TCEP, TCPP, DEET and NBBS. Published data of metformin, narasin and ciprofloxacin were tested in separate pots
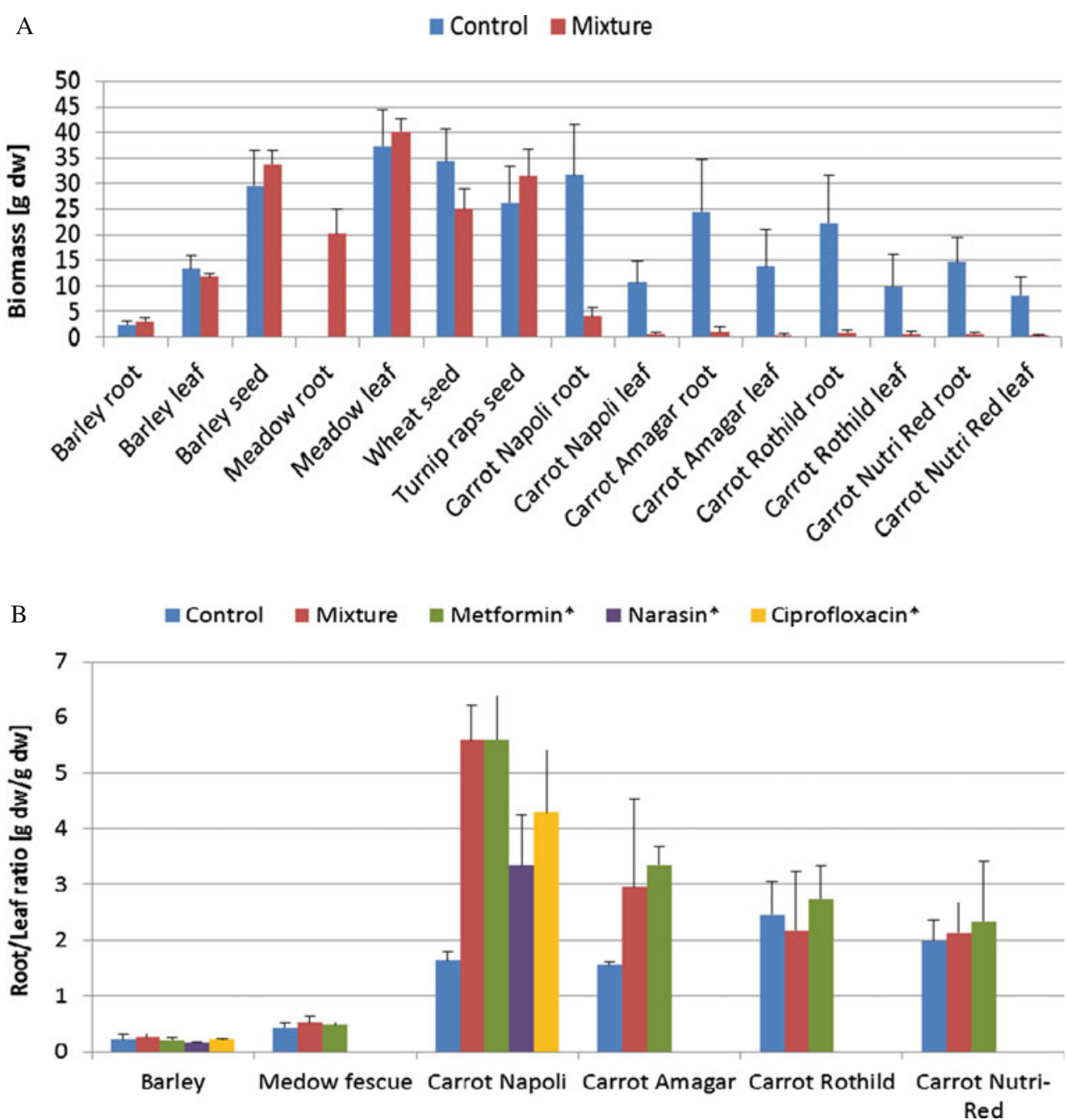

sensitive to phytotoxins (EuropeanFoodSafetyAuthorities 2008; Migliore et al. 2003). The results of the present study confirm that there can be variation between different species and even cultivars of the same species after exposure to these emerging contaminants.

Environmental and food safety relevance

There is an increasing number of emerging contaminants in the environment, including pharmaceuticals and different kinds of additives used in everyday products. These compounds can reach the terrestrial or aquatic food web through transfer from consumer products into wastewater from homes, hospitals and industries or by leaching into groundwater when disposed of in municipal landfills (Table 1). WWTPs discharge to lakes and seas and thus influence the aquatic food web, while sewage sludge is applied to soil or soil mixtures used for cultivation of crops. Organophosphates have been found in marine and freshwater biota (mussels, crab, fish) (Evenset et al. 2009; Leonards et al. 2011; Sundkvist et al. 2010), human milk (Sundkvist et al. 2010) and drinking water
(Galassi et al. 1989 TCPP, which in the present study shows high uptake in carrot root and forage grass, has been detected in fish muscles in capelin and in milk and plasma in harbour seal (Sagerup et al. 2011; Sundkvist et al. 2010).

A TCEP risk assessment from 2009 claimed that "since there is no indication that TCEP may show a bioaccumulation potential, a risk characterization for exposure via the food chain is not necessary" (European Commission 2009). Similarly, a risk assessment for TCPP states that owing to "... lack of any significant bioaccumulation potential of TCPP, it is reasonable to conclude that there are no risks" (European Commission 2008). Based on the experimental bioconcentration factors for TCEP and TCPP, the high variation between species found in the present study and the relatively long half-life in soil and a persistency potential, there is reason to investigate the transfer and possible bioaccumulation of these compounds in food webs more deeply.

More generic knowledge about the relationship between the chemical properties of various compounds, uptake mechanisms into crops and plant composition is necessary 
in order to perform health risk assessments where soil-plant transfer is part of the exposure route. Such knowledge is also important for identification and prediction of compounds with potentially high transfer to human and livestock food webs. Regulatory authorities should pay special attention to these compounds, and measures to reduce or remove sources should be introduced in an early phase. This is also valuable knowledge for food authorities devising restrictions or recommendations for cultivation of certain crops in areas with enhanced levels of organic compounds.

\section{Conclusions}

In this 17-week pot experiment, the organophosphates TCEP and TCPP generally exhibited higher uptake and translocation in crop plants than TBP, the insect repellent DEET and the plasticiser NBBS, despite DEET and NBBS having comparable $\log K_{\text {ow }}$ values as TCEP. Although TCEP and TCPP had similar properties, there were clearly species-specific uptake patterns in meadow fescue, barley and carrot. The surprisingly high translocation of TCPP into leaves of meadow fescue, a livestock forage species, is of particular concern and highlights the necessity for further studies investigating the effects of these compounds in the food web, to improve regulatory guidelines.

Acknowledgements The authors would like to thank Isak Drozdik, Mette Hjermann, Henk Maessen and Hans Martin Hanslin for their valuable contributions throughout the growth experiment and Dr. H.M. Hanslin for statistical work. We also thank the Norwegian Research Council, the Food Programme, for financial support (1848339/I10 to TE).

\section{References}

Andresen JA, Grundmann A, Bester K (2004) Organophosphorus flame retardants and plasticisers in surface waters. Sci Tot Environ 332:155-166

Aronson D, Weeks J, Guiney PD, Howard PH (2011) Environmental release, environmental concentrations, and ecological risk of $N$, $N$-diethyl-m-toluamide (DEET). Integr Environ Assess Manag 8:135-166

Boxall ABA, Johnson P, Smith EJ, Sinclair CJ, Stutt E, Levy LS (2006) Uptake of veterinary medicines from soils into plants. J Agr Food Chem 54:2288-2297

Briggs GG, Bromilow RH, Evans AA (1982) Relationship between lipophilicity and root uptake and translocation of non-ionised chemicals by barley. Pestic Sci 13:495-504

Calderón-Preciado D, Jiménez-Cartagena C, Matamoros V, Bayona JM (2011) Screening of 47 organic microcontaminants in agricultural irrigation waters and their soil loading. Water Res 45:221-231

Campagnolol ER, Johnson KR, Karpati A, Rubin CS, Kolpin DW, Meyer MT, Esteban JE, Currier RW, Smith K, Thu KM, McGeehin M (2002) Antimicrobial residues in animal waste and water resouces proximal to large-scale swine and poultry feeding operations. Sci Total Environ 299:89-95
Chiou CT, Sheng G, Manes M (2001) A partition-limited model for the plant uptake of organic contaminants from soil and water. Environ Sci Technol 35:1437-1444

Clarke BO, Smith SR (2011) Review of 'emerging' organic contaminants in biosolids and assessment of international research priorities for the agricultural use of biosolids. Environ Int 37:226-247

Collins CD, Willey NJ (2009) Phylogenetic variation in the tolerance and uptake of organic contaminants. Int $\mathrm{J}$ Phytoremediation 11:623-639

Dettenmaier EM, Doucette WJ, Bugbee B (2009) Chemical hydrophobicity and uptake by plant roots. Environ Sci Technol 43:324-329

Díaz-Cruz MS, García-Galán MJ, Guerra P, Jelic A, Postigo C, Eljarra E, Farré M, López de Alda MJ, Petrovic M, Barceló D (2009) Analysis of selected emerging contaminants in sewage sludge. Trends in Anal Chem 28:1263-1275

Doucette WJ, Chard JK, Moore BJ, Staudt WJ, Headley JV (2005) Uptake of sulfolane and diisopropanolamine (DIPA) by cattails (Typha latifolia). Microchem J 81:41-49

Duarte-Davidson R, Jones KC (1996) Screening the environmental fate of organic contaminants in sewage sludge applied to agricultural soils: II. The potential for transfers to plants and grazing animals. Sci Total Environ 185:59-70

Eggen T, Lillo C (2012) Antidiabetic II drug metformin in plants: uptake and translocation to edible parts of cereals, oily seeds, beans, tomato, squash, carrots, and potatoes. J Agric Food Chem 60:6929-6935

Eggen T, Asp TN, Grave K, Hormazabal V (2011) Uptake and translocation of metformin, ciprofloxacin and narasin in forage- and crop plants. Chemosphere 85:26-33

Eriksson E, Auffarth K, Eilersen A-M, Henze M, Ledin A (2003) Household chemicals and personal care products as sources for xenobiotic organic compounds in grey wastewater. Water SA 29:135-146

European Commission (2008) EU risk assessment report, tris(2-chloro1-methylethyl)phosphate (TCPP)

European Commission (2009) Risk assessment report, tris(2-chloroethyl)phosphate (TCEP), draft 2009

European Food Safety Authorities (2008) Panel on additives and products or substances used in animal feed. http://www.efsa. europa.eu/en/scdocs/doc/1574.pdf

Evenset A, Leknes H, Christensen GN, Warner N, Remberger M, Gabrielsen GW (2009) Screening of new contaminants in samples from the Norwegian Artic. SPFO-report 1049/2009. TA-2510/2009

Ficko SA, Rutter A, Zeeb BA (2010) Potential for phytoextraction of PCBs from contaminated soils using weeds. Sci Tot Environ 408:3469-3476

Furtula V, Farrell EG, Diarrassoba F, Rempel H, Pritchard J, Diarra MS (2010) Veterinary pharmaceuticals and antibiotic resistance of Escherichia coli isolates in poultry litter from commercial farms and controlled feeding trials. Poultry Sci 29:180-188

Galassi S, Guzzella L, Sora S (1989) Mutagenic potential of drinking waters from surface supplies in Northern Italy. Enviro Tox Chem 8:109-116

Gao Y, Zhu L, Ling W (2005) Application of the partition-limited model for plant uptake of organic chemicals from soil and water. Sci Total Environ 336:171-182

Glassmeyer ST, Furlong ET, Kolpin DW, Cahill JD, Zaugg SD, Werner SL (2005) Transport of chemical and microbial compounds from known wastewater discharges: potential for use as indicators of human fecal contamination. Environ Sci Technol 39:5157-5169

Goldman LR (1998) Chemicals and children's enviornment: what we don't know about risks. Environ Health Perspect 106:875-880

Gonzalez M, Miglioranza KSB, Aizpún de Moreno JE, Moreno VJ (2005) Evaluation of conventionally and organically produced vegetables for high lipophilic organochlorine pesticide (OCP) residues. Food Chem Toxicol 43:261-269 
Green NS, Bakke M. Brevik T, Dye EM, Herzke D, Huber S, Plosz B, Remberger M, Schøyen M, Uggerud HT, Vogelsang C (2008) Screening of selected metals and new organic contaminants 2007. Phosphorus flame retardents, polyfluorinated organic compounds, nitro-PAHs, silver, platinum and sucralose in air, wastewater treatment facilities, and recipients. Norwegian Pollution Control Authority, Oslo, Norway

Hansch C, Steinmetz WE, Leo AJ, Mekapati SB, Kurup A, Hoekman D (2003) On the role of polarizability in chemical-biological interactions. J Chem Inf Comput Sci 43:120-125

Harrison EZ, Oakes SR, Hysell M, Hay A (2006) Organic chemicals in sewage sludges. Review Sci Total Environ 367:481-497

Heimstad ES, Smalaas AO, Kallenborn R (2001) Environmental fate of chlorinated bornanes estimated by theoretical descriptors. Chemosphere 43:665-674

Herklotz PA, Gurung P, Heuvel BV, Kinney CA (2010) Uptake of human pharmaceuticals by plants grown under hydroponic conditions. Chemosphere 78:1416-1421

Hong Q, Chen JW, Wang Y, Wang B, Li XH, Li F, Wang YN (2009) Development and assessment of quantitative structureactivity relationship models form bioconcentration factors of organic pollutants. Chinese Sci Bulletin 54:628-634

Huppert N, Würtele M, Hahn HH (1998) Determination of the plasticizer $N$-butylbenzenesulfonamide and the pharmaceutical Ibuprofen in wastewater using solid phase microextraction (SPME). Fresenius J Anal Chem 362:529-536

Inui H, Wakai T, Gion K, Kim Y-S, Eun H (2008a) Differential uptake for dioxin-like compounds by zucchini subspecies. Chemosphere 73:1602-1607

Inui H, Wakai T, Gion K, Kim Y-S, Eun H (2008b) Differential uptake for dioxin-like compounds by zucchini subspecies. Chemosphere 73:1602-1607

Karelson M, Lobanov VS (1996) Quantum-chemical descriptors in QSAR/QSPR studies. Chem Rev 96:1027-1043

Kelsey JW, White JC (2005) Multi-species interactions impact the accumulation of weathered 2,2-bis ( $p$-chlorophenyl)-1,1-dechloroethylene ( $p, p$-DDE) from soil. Environ Pollution 137:222230

Khan Z, Doty S (2011) Endophyte-assisted phytoremediation. Current Opinion in Plant Biology 12:97-105

Kolpin DW, Furlong ET, Meyer MT, Thurman EM, Zaugg SD, Barber LB, Buxton HT (2002) Pharmaceuticals, hormones, and other organic wastewater contaminants in U.S. streams, 1999-2000: a national reconnaissance. Environ Sci Technol $36: 1202-1211$

Lee I-S, Lee S-H, Oh J-E (2010) Occurrence and fate of synthetic musk compounds in water environment. Wat Res 44:214-222

Lehotay SJ, Mastovska K, Lightfield AR (2005) Use of buffering and other means to improve results of problematic pesticides in a fast and easy method for residue analysis of fruits and vegetables. $\mathrm{J}$ AOAC Int 88:615-629

Leonards P, Steindal EH, van der Veen I, Berg V, Bustnes JO, van Leeuwen S (2011) Screening of organophosphor flame retardants 2010. SPFO-report 1091/2011. TA-2786/2011

Li H-Y, Wei D-Q, Shen M, Zhou Z-P (2012) Endophytes and their role in phytoremediation. Fungal Diversity 54:11-18

Lunney AI, Zeeb BA, Reimer KJ (2004) Uptake of weathered DDT in vascular plants: potential for phytoremediation. Environ Sci Technol 38:6147-6154

Macherius A, Eggen T, Lorenz WG, Reemtsma T, Winkler U, Möder M (2012) Uptake of galaxolide, tonalide, and triclosan by carrot, barley, and meadow fescue plants. J Agric Food Chem 60:77857791

Marklund A, Andersson B, Haglund P (2003) Screening of organophosphorus compounds and their distribution in various indoor environments. Chemosphere 53:1137-1146
Marklund A, Andersson B, Haglund P (2005) Organophosphorus flame retardants and plasticizers in Swedish Sewage Treatment Plants. Environ Sci Technol 39:7423-7429

Marschner H (1995) Mineral nutrition of higher plants. Academic Press, Second Edition

Mattina MJI, Isleyen M, Eitzer BD, Iannucci-Berger W, White JC (2006) Uptake by Cucurbitaceae of soil-born contaminants depends upon plant genotype and pollutant properties. Environ Sci Technol 40:1814-1821

McFarlane JC (1995) Anatomy and physiology of plant conductive systems. In: McFarlane JC, Trapp S (eds) Plant contamination. Modeling and simulation of organic chemical processes. Lewis Publishers, Boca Raton, FL

Migliore L, Brambilla G, Casoria P, Civitareale C, Cozzolino S, Gaudio L (1996) Effect of sulphadimethoxine contamination on barley (Hordeum distichum L., Poaceae, Liliopsida). Agr Ecosyst Environ 60:121-128

Migliore L, Cozzolino S, Fiori M (2003) Phytotoxicity to and uptake of enrofloxacin in crop plants. Chemosphere 52:12331244

Muñoz I, Gómez-Ramos MJ, Agüera A, García-Reyes JF, MolinaDíaz A, Fernández-Alba AR (2009) Chemical evaluation of contaminants in wastewater effluents and the environmental risk of reusing effluents in agriculture. Trends Anal Chem 28:676-694

Murano H, Otani T, Seike N, Sakai M (2010) Dieldrin uptake and translocation in plants growing in hydroponic medium. Enviro Tox Chem 29:142-148

Nakada N, Tanishima T, Shinohara H, Kiri K, Takada H (2006) Pharmaceutical chemicals and endocrine disrupters in municipal wastewater in Tokyo and their removal during activated sludge treatment. Water Res 40:3297-3303

Nakada N, Yasojima M, Okayasu Y, Komori K, Suzuki Y (2010) Mass balance analysis of triclosan, diethyltoluamide, crotamiton and carbamazepine in sewage treatment plants. Wat Sci Technol 61:1739-1747

OECD (April 2001) (updated March 2002) Tributyl phosphate, UNEP publication

Papa E, Dearden JC, Gramatica P (2007) Linear QSAR regression models for the prediction of bioconcentration factors by physicochemical properties and structural theoretical molecular descriptors. Chemosphere 67:351-358

Quednow K, Püttmann W (2009) Temporal concentration changes of DEET, TCEP, terbutryn, and nonylphenols in freshwater streams of Hesse, Germany: possible influence of mandatory regulations and voluntary environmental agreements. Environ Sci Pollut Res $16: 630-640$

Reemtsma T, Weiss S, Mueller J, Petrovic M, Gonzalez S, Barcelo D, Ventura F, Knepper T (2006) Polar pollutants entry into the water cycle by municpal wastewater: a European perspective. Environ Sci Technol 40:5451-5458

Reemtsma T, Quintana JB, Rodil R, García-López M, Rodríguez I (2008) Organophosphorus flame retardants and plasticizers in water and air I. Occurrence and fate Trends in Anal Chem 27:727-737

Rein A, Legind CN, Trapp S (2011) New concepts for dynamic plant uptake models. SAR QSAR Environ Res 22:191-215

Ryan JA, Bell RM, Davidson JM, O'Connor GA (1988) Plant uptake of non-ionic organic chemicals from soils. Chemosphere 17:2299-2323

Sagerup K, Leonards P, Routti H, Fuglei E, Aars J, Strøm H, Kovacs K, Lydersen C, Gabrielsen GW 2011 Organophophous flame retardants in Arctic biota

Schröder P, Scheer CE, Diekmann F, Stampfl A (2007) How plants cope with foreign compounds. Environ Sci Pollut Res 14:114 122 
Slack RJ, Gronow JR, Voulvoulis N (2005) Household hazardous waste in municipal landfills: contaminants in leachate. Sci Total Environ 337:119-137

Staikovaa M, Waniab F, Donaldson DJ (2004) Molecular polarizability as a single-parameter predictor of vapour pressures and octanolair partitioning coefficients of non-polar compounds: a priori approach and results. Atmosph Environ 38:213-225

Strong MJ, Garruto RM, Wolff AV, Chou SM, Fox SD, Yanagihara R (1991) $\mathrm{N}$-butyl benzenesulfonamide - a neurotoxic plasticizer inducing a spastic myelopathy in rabbits. Acta Neuropathologica 81:235-241

Sundkvist AM, Olofsson U, Haglund P (2010) Organophosphorus flame retardants and plastiizers in marine and fresh water biota and in human milk. J Environ Monit 12:943-951

Terzic S, Senta I, Ahel M, Gros M, Petrovic M, Barceló D, Müller J, Knepper T, Martí I, Ventura F, Jovancic P, Jabucar D (2008) Occurrence and fate of emerging wastewater contaminants in Western Balkan Region. Sci Total Environ 399:66-77

Trapp S (2000) Modelling uptake into roots and subsequent translocation of neutral and ionisable organic compounds. Pest Manag Sci $56: 767-778$

van Leeuwen CJ, Vermeire TG (2007) Risk assessment of chemicals: an introduction. Springer, Dordrecht, The Netherlands

Verma RP, Kurup A, Hansch C (2005) On the role of polarizability in QSAR. Bioorg Med Chem 13:237-255

White JC (2002) Differential bioavailability of field-weathered $p, p 0$-DDE to plants of the Cucurbita and Cucumis genera. Chemosphere 49:143-152

White JC (2010) Inheritance of $p, p^{\prime}$-DDE phytoextraction ability in hybridized Cucurbita pepo. Cultivars Environ Part Sci Technol 44:5165-5169

White JC, Mattina MJI, Lee W-Y, Eitzer BD, Iannucci-Berger W (2003a) Role of organic acids in enhancing the desorption and uptake of weathered $p, p^{\prime}$-DDE by Cucurbita pepo. Environ Pollut 124:71-80

White JC, Wang X, Gen MPN, Iannucci-Berger W, Eitzer BD, Schultes NP, Arienzo M, Mattina MJI (2003b) Subspecies-level variation in the phytoextraction of weathered $p, p^{\prime}$-DDE by Cucurbita pepo. Environ Sci Technol 37:4368-4373

Whitfield-Åslund ML, Rutter A, Reimer KJ, Zeeb BA (2008) The effects of repeated planting, planting density, and specific transfer pathways on PCB uptake by Cucurbita pepo grown in field conditions. Sci Total Environ 405:14-25

WHO (World Health Organization 1998) International program on chemical safety, environmental health criteria 209, flame retardants: tris-(chloropropyl)phosphate and tris-(2- chloroethyl)phosphate. WHO, Geneva, Switzerland

Winker M, Clemens J, Reich M, Gulyas H, Otterpohl R (2010) Ryegrass uptake of carbamazepine and ibuprofen applied by urine fertilization. Sci Tot Environ 408:1902-1908

Wu C, Spongberg AL, Witter JD, Fang M, Czajkowsk KP (2010) Uptake of pharmaceutical and personal care products by soybean plants from soils applied with biosolids and irrigated with contaminated water. Environ Sci Technol 44:6157-6161

Zhang H, Chen J, Ni Y, Zhang Q, Zhao L (2009) Uptake by roots and translocation to shoots of polychlorinated dibenzo-p-dioxins and dibenzofurans in typical crop plants. Chemosphere 76:740-746

Zhao L, Dong YH, Wang H (2010) Residues of veterinary antibiotics in manures from feedlot livestock in eight provinces of China. Sci Total Environ 408:1069-1075

Zohair A, Salim A-B, Soyibo AA, Beck AJ (2006) Residues of polycyclic aromatic hydrocarbons (PAHs), polychlorinated biphenyls (PCBs) and organochlorine pesticides in organicallyfarmed vegetables. Chemosphere 63:541-553 